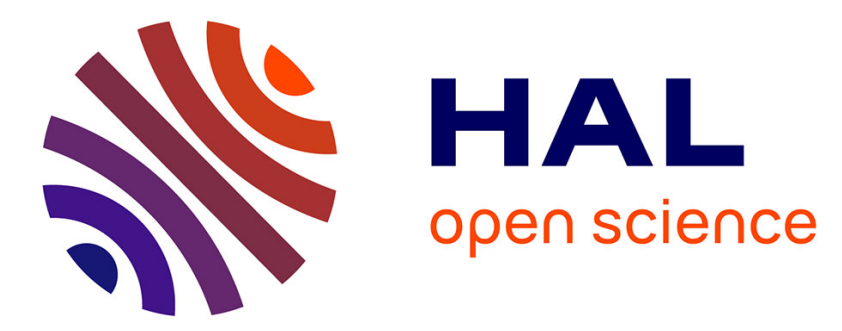

\title{
High-quality highly strained InGaAs quantum wells grown on InP using (InAs)n(GaAs)0.25 fractional monolayer superlattices
}

\author{
S. Jourba, M. Gendry, O. Marty, M. Pitaval, G. Hollinger
}

\section{To cite this version:}

S. Jourba, M. Gendry, O. Marty, M. Pitaval, G. Hollinger. High-quality highly strained InGaAs quantum wells grown on InP using ( InAs)n( $\mathrm{GaAs}) 0.25$ fractional monolayer superlattices. Applied Physics Letters, 1999, 75 (2), pp.220-222. 10.1063/1.124328 . hal-02111923

\section{HAL Id: hal-02111923 \\ https://hal.science/hal-02111923}

Submitted on 26 Apr 2019

HAL is a multi-disciplinary open access archive for the deposit and dissemination of scientific research documents, whether they are published or not. The documents may come from teaching and research institutions in France or abroad, or from public or private research centers.
L'archive ouverte pluridisciplinaire HAL, est destinée au dépôt et à la diffusion de documents scientifiques de niveau recherche, publiés ou non, émanant des établissements d'enseignement et de recherche français ou étrangers, des laboratoires publics ou privés. 


\title{
High-quality highly strained InGaAs quantum wells grown on InP using $(\operatorname{InAs})_{n}(\mathrm{GaAs})_{0.25}$ fractional monolayer superlattices
}

\author{
S. Jourba ${ }^{\text {a) }}$ and M. Gendry \\ Laboratoire d'Electronique, Optoélectronique et Microsystèmes (LEOM), UMR CNRS 5512, Ecole Centrale \\ de Lyon, 69131 Ecully Cedex, France \\ O. Marty and M. Pitaval \\ Département de Physique des Matériaux (DPM), UMR CNRS 5586, Université Lyon 1, 69662 Villeurbanne \\ Cedex, France \\ G. Hollinger \\ Laboratoire d'Electronique, Optoélectronique et Microsystèmes (LEOM), UMR CNRS 5512, Ecole Centrale \\ de Lyon, 69131 Ecully Cedex, France
}

(Received 9 March 1999; accepted for publication 14 May 1999)

$(\mathrm{InAs})_{n} /(\mathrm{GaAs})_{m}(n=1.5-2, m=0.25$ monolayer) fractional monolayer superlattices (FMS) have been used to grow highly strained InGaAs quantum wells (QWs) on InP by molecular beam epitaxy. We show that FMS quantum wells have better structural and optoelectronic properties compared to equivalent QWs grown using standard procedures. In addition, the onsets of the three-dimensional growth mode and plastic relaxation are delayed, which allows the highest emission wavelength in the $\mathrm{In}_{x} \mathrm{Ga}_{1-x} \mathrm{As} / \mathrm{InGaAlAs} / \mathrm{InP}$ system to be extended up to $2.35 \mu \mathrm{m}$ at high growth temperatures $\left(500{ }^{\circ} \mathrm{C}\right)$. (C) 1999 American Institute of Physics. [S0003-6951(99)00228-4]

Highly strained $\operatorname{In}_{x} \mathrm{Ga}_{1-x} \mathrm{As} / \mathrm{InP}$ quantum wells (QWs) grown on InP substrates are highly desirable for near infrared lasers ${ }^{1,2}$ and resonant photodetectors ${ }^{3,4}$ operating in the 1.7$2.5 \mu \mathrm{m}$ wavelength range. The most important applications include gas detection, spectroscopy, and spectral imaging. The longest room temperature operation wavelength achieved to date is $2.2 \mu \mathrm{m}$ for In compositions in the $0.85-$ 0.90 range and a thickness of about $75 \AA$. Longer wavelengths could be achieved by increasing the quantum well thickness. However, above a critical thickness, a twodimensional (2D)/three-dimensional (3D) growth mode transition occurs, rapidly followed by relaxation through dislocations. This plastic relaxation makes it difficult to maintain good optoelectronic quality.

It is known that spontaneous or artificial lateral composition modulation helps to decrease the strain energy and delay the plastic relaxation of strained materials. ${ }^{5}$ Such lateral strain compensation or strain-induced lateral ordering (SILO) has already been observed in (InAs) ${ }_{n} /(\mathrm{GaAs})_{m}$ and $(\mathrm{InAs})_{n} /(\mathrm{AlAs})_{m}$ short period superlattices grown on InP., More generally, it has also been found that $(\mathrm{InAs})_{n} /(\mathrm{GaAs})_{m}[n, m=1-3$ monolayers (ML) $]$ strained short period superlattices are a promising alternative to InGaAs random ternary alloys. Higher electron mobilities are expected due to minimization of alloy scattering. ${ }^{8}$ It has also been found that the critical thickness for plastic relaxation is increased. This effect has been used to extend the optical emission range of InGaAs QWs grown on GaAs up to $1.23 \mu \mathrm{m} .^{9}$

In this letter, we show that highly strained InGaAs QWs grown on InP using $(\mathrm{InAs})_{n} /(\mathrm{GaAs})_{m}$ fractional monolayer superlattices (FMS) have better structural and optoelectronic properties compared to QWs grown using standard procedures. In addition, the onset of the 3D growth mode as well

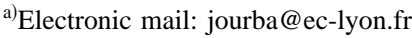

as that of plastic relaxation are delayed which allows the longest emission wavelength in the $\mathrm{In}_{x} \mathrm{Ga}_{1-x} \mathrm{As} / \mathrm{InGaAlAs} / \mathrm{InP}$ system to be extended to 2.35 $\mu \mathrm{m}$. In order to reach an average indium composition of $n /(n+m)=0.85-0.90, n$ was taken between 1.5 and $2 \mathrm{ML}$ and $m$ was kept equal to $0.25 \mathrm{ML}$.

The samples were grown by molecular beam epitaxy (MBE) on semi-insulating $\operatorname{InP}(001)$ substrates. The structures consist of, from bottom to top, a $4000 \AA$ $\mathrm{In}_{0.53} \mathrm{Ga}_{0.27} \mathrm{Al}_{0.2} \mathrm{As}$ (band gap $\sim 1.01 \mathrm{eV}$ ) buffer layer, a 100 $\AA \mathrm{In}_{0.53} \mathrm{Ga}_{0.47}$ As barrier layer, a $\left[(\mathrm{InAs})_{n} /(\mathrm{GaAs})_{0.25}\right]$ FMS quantum well, a second $100 \AA \mathrm{In}_{0.53} \mathrm{Ga}_{0.47} \mathrm{As}$ barrier layer, and a $3000 \AA \mathrm{In}_{0.53} \mathrm{Ga}_{0.27} \mathrm{Al}_{0.2}$ As cap layer. The layer index $n$ was varied from 1.5 to 2 . In reference samples, the FMS quantum well is replaced by an $\operatorname{In}_{x} \mathrm{Ga}_{1-x}$ As quantum well of the same thickness with $x=n /(n+0.25)$. Before growth, InP substrates were de-oxidized under $\mathrm{As}_{4}$ flux at $565^{\circ} \mathrm{C}$ for 90 s. For most samples, the growth temperature was $500^{\circ} \mathrm{C}$ in order to obtain good optoelectronic properties. Comparative experiments was performed with samples grown at $450{ }^{\circ} \mathrm{C}$ which are known to have lower optoelectronic properties. The $\operatorname{In}_{0.53} \mathrm{Ga}_{0.47} \mathrm{As}$ barriers were used to smooth the growth front and to limit quantum confinement effects. The growth rates were $\sim 1 \mu \mathrm{m} / \mathrm{h}$ for both quaternary InGaAlAs buffer and cap layers and $0.6 \mu \mathrm{m} / \mathrm{h}$ for $\operatorname{In}_{0.53} \mathrm{Ga}_{0.47} \mathrm{As}$ barrier layers. In and $\mathrm{Ga}$ fluxes, identical to those used for the $\mathrm{In}_{0.53} \mathrm{Ga}_{0.47} \mathrm{As}$ barriers, were used to grow the superlattice. The corresponding InAs and GaAs growth rates are $\sim 0.29$ and $\sim 0.25 \mathrm{ML}$ per second, respectively. The V/III beam equivalent pressure ratios were 15 for InGaAlAs, 30 for $\mathrm{In}_{0.53} \mathrm{Ga}_{0.47} \mathrm{As}$, and 60 for InAs and GaAs. All layers were undoped. No growth interruption was performed during growth of the FMS structures. The 2D/3D growth mode transition was monitored by in situ reflection high-energy electron diffraction (RHEED).

Photoluminescence (PL) measurements were performed 
TABLE I. $h_{3 \mathrm{D}}$ critical thickness for the 2D/3D growth mode transition determined by RHEED for $\operatorname{In}_{x} \mathrm{Ga}_{1-x}$ As strained layers grown by conventional $\mathrm{MBE}$ at $500^{\circ} \mathrm{C}$ and for equivalent InAs/GaAs FMS.

\begin{tabular}{cccc}
\hline \hline $\begin{array}{c}\text { Average } \\
\text { composition }\end{array}$ & Equivalent FMS & $\begin{array}{c}\text { Conventional MBE } \\
h_{3 \mathrm{D}}(\AA)\end{array}$ & $\begin{array}{c}\text { FMS } \\
h_{3 \mathrm{D}}(\AA)\end{array}$ \\
\hline $\mathrm{In}_{0.85} \mathrm{Ga}_{0.15} \mathrm{As}$ & $(\mathrm{InAs})_{1.5}(\mathrm{GaAs})_{0.25}$ & 42 & No 3D \\
$\mathrm{In}_{0.87} \mathrm{Ga}_{0.13} \mathrm{As}$ & $(\mathrm{InAs})_{1.75}(\mathrm{GaAs})_{0.25}$ & 35 & 80 \\
$\mathrm{In}_{0.89} \mathrm{Ga}_{0.11} \mathrm{As}$ & $(\mathrm{InAs})_{2}(\mathrm{GaAs})_{0.25}$ & 30 & 65 \\
\hline \hline
\end{tabular}

at room temperature (RT) and at $77 \mathrm{~K}$ using an $\mathrm{AlGaAs}$ laser diode emitting at $800 \mathrm{~nm}$ and a liquid nitrogen cooled InAs detector. The structural quality of the samples was investigated by Nomarski optical microscopy and by crosssectional transmission electron microscopy (TEM) using a JEOL microscope operating at $200 \mathrm{kV}$.

We grew a series of FMS and standard QWs with In compositions varying from 0.85 to 0.89 at growth temperatures of 450 and $500{ }^{\circ} \mathrm{C}$. It was found that the first clear advantage of FMS growth is to increase the critical thickness for the 2D/3D growth mode transition with respect to equivalent QWs grown by conventional MBE. Examples are given in Table I for three quantum wells of different compositions grown at $500{ }^{\circ} \mathrm{C}$. The critical thickness is increased from 30 to 65 and from 35 to $80 \AA$ for $\operatorname{In}_{0.89} \mathrm{Ga}_{0.11} \mathrm{As}$ and $\mathrm{In}_{0.87} \mathrm{Ga}_{0.13} \mathrm{As}$, respectively. For $\mathrm{In}_{0.85} \mathrm{Ga}_{0.15} \mathrm{As}$, the $2 \mathrm{D} / 3 \mathrm{D}$ critical thickness is around $42 \AA$ in conventional MBE whereas no $2 \mathrm{D} / 3 \mathrm{D}$ transition is observed for the equivalent $\left[(\mathrm{InAs})_{1.5} /(\mathrm{GaAs})_{0.25}\right] \mathrm{QW}$. Plastic relaxation occurs in the $2 \mathrm{D}$ growth mode at $\sim 90 \AA$.

Table II and Figs. 1 and 2 present comparative data on the emission wavelength and the optoelectronic quality for QWs grown using both conventional MBE and fractional monolayer superlattices for two compositions, $\mathrm{In}_{0.85} \mathrm{Ga}_{0.15} \mathrm{As}$ and $\mathrm{In}_{0.89} \mathrm{Ga}_{0.11} \mathrm{As}$, and two growth temperatures, 500 and $450{ }^{\circ} \mathrm{C}$.

Figure 1 shows the RT and $77 \mathrm{~K}$ photoluminescence spectra from the pseudomorphic $\left[(\mathrm{InAs})_{1.5} /(\mathrm{GaAs})_{0.25}\right] \times 8$ FMS QW and from the corresponding $\mathrm{In}_{0.85} \mathrm{Ga}_{0.15} \mathrm{As}$ reference sample grown by conventional MBE. The $40 \AA \mathrm{QW}$ thickness was chosen to be just below the critical thickness of the 3D growth mode in conventional MBE. At room temperature, the PL peak intensity is 3.5 times higher for the FMS QW than for the conventional QW. The conventional QW exhibits a $19 \mathrm{meV}$ PL linewidth at $77 \mathrm{~K}$, whereas it is

TABLE II. Emission wavelengths at room temperature and optoelectronic quality of $\mathrm{In}_{x} \mathrm{Ga}_{1-x}$ As quantum wells grown by conventional MBE and by the FMS technique for two indium compositions. Relaxed materials have poor optoelectronic quality.,+++++ and + mean high, average, and low quality, respectively.

\begin{tabular}{cccccc}
\hline \hline & & & & \multicolumn{2}{c}{$\begin{array}{c}\text { Optoelectronic } \\
\text { quality }\end{array}$} \\
\cline { 5 - 6 } $\begin{array}{c}\text { Average } \\
\text { composition }\end{array}$ & $\begin{array}{c}\text { Growth } \\
\text { temperature } \\
\left({ }^{\circ} \mathrm{C}\right)\end{array}$ & $\begin{array}{c}\text { Well } \\
\text { thickness } \\
(\AA)\end{array}$ & $\begin{array}{c}\text { Emission } \\
\text { wavelength } \\
(\mu \mathrm{m})\end{array}$ & $\begin{array}{c}\text { Standard } \\
\text { MBE }\end{array}$ & $\begin{array}{c}\text { FMS } \\
\text { growth }\end{array}$ \\
\hline $\mathrm{In}_{0.85} \mathrm{Ga}_{0.15} \mathrm{As}$ & 500 & 40 & 2.02 & ++ & +++ \\
& 450 & 75 & 2.22 & 2D relaxed & + \\
$\mathrm{In}_{0.89} \mathrm{Ga}_{0.11} \mathrm{As}$ & 500 & 60 & 2.35 & 3D relaxed & +++ \\
& 500 & 90 & 2.40 & 3D relaxed & 3D relaxed \\
& 450 & 140 & 2.50 & 2D relaxed & 2D relaxed
\end{tabular}
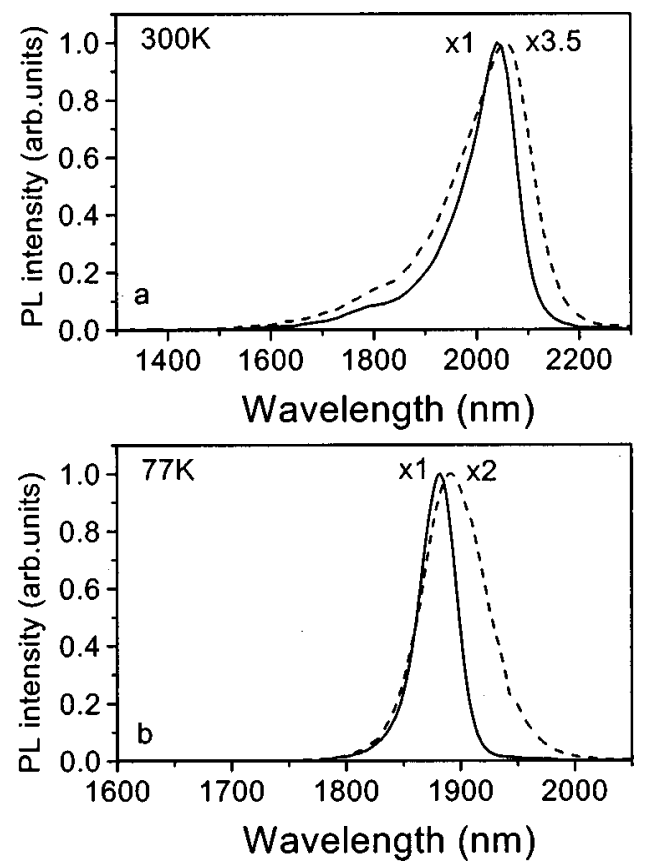

FIG. 1. $300 \quad \mathrm{~K} \quad$ (a) and $77 \quad \mathrm{~K} \quad$ (b) $\mathrm{PL}$ spectra from $40 \quad \AA$ $\mathrm{In}_{0.85} \mathrm{Ga}_{0.15} \mathrm{As} / \mathrm{InGaAlAs} \mathrm{QWs}$ grown by conventional MBE (dashed lines) and using (InAs) $)_{1.5} /(\mathrm{GaAs})_{0.25}$ FMS as material for the QWs. In both cases, the growth temperature is $500{ }^{\circ} \mathrm{C}$. At $77 \mathrm{~K}$, the full widths at half maximum of the PL peaks are 19 and $10 \mathrm{meV}$, respectively.

only $10 \mathrm{meV}$ for the FMS sample. Commonly, quantum well PL linewidth broadening is attributed to QW thickness fluctuations and/or compositional in-plane inhomogeneities.

Decreasing the growth temperature to $450{ }^{\circ} \mathrm{C}$ allows the $3 \mathrm{D}$ growth mode to be suppressed in conventional MBE, so thicker layers can be grown. Table II shows that a $75 \AA$ pseudomorphic $\mathrm{In}_{0.85} \mathrm{Ga}_{0.15}$ As QW was successfully grown using the FMS procedure with a PL intensity characteristic of nonrelaxed strained QWs grown at such a temperature $\left(\sim 10\right.$ times lower than at $\left.500^{\circ} \mathrm{C}\right)$. In contrast, plastic relaxation via $[1 \overline{1} 0]$ oriented dislocations occurs for the conventionally grown $\operatorname{In}_{0.85} \mathrm{Ga}_{0.15} \mathrm{As} \mathrm{QW}$, which leads to a dramatic decrease of PL intensity.

The above results show that the FMS approach allows both elastic relaxation (3D growth mode) and plastic relaxation in the 2D growth mode to be delayed. This means that the In composition can be increased and thicker pseudomorphic strained QWs can be grown to reach longer operating

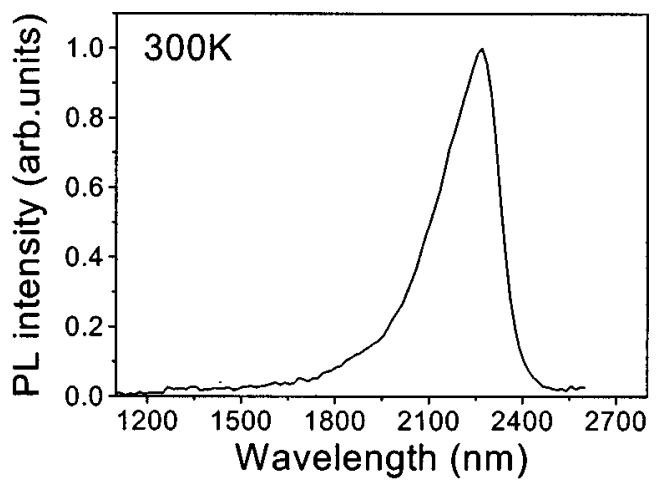

FIG. 2. $300 \mathrm{~K}$ PL spectra from a $60 \AA \operatorname{In}_{0.89} \mathrm{Ga}_{0.11} \mathrm{As} / \mathrm{InGaAlAs}$ FMS QW grown at $500{ }^{\circ} \mathrm{C}$.

Downloaded 10 Oct 2003 to 156.18.34.206. Redistribution subject to AIP license or copyright, see http://ojps.aip.org/aplo/aplcr.jsp 


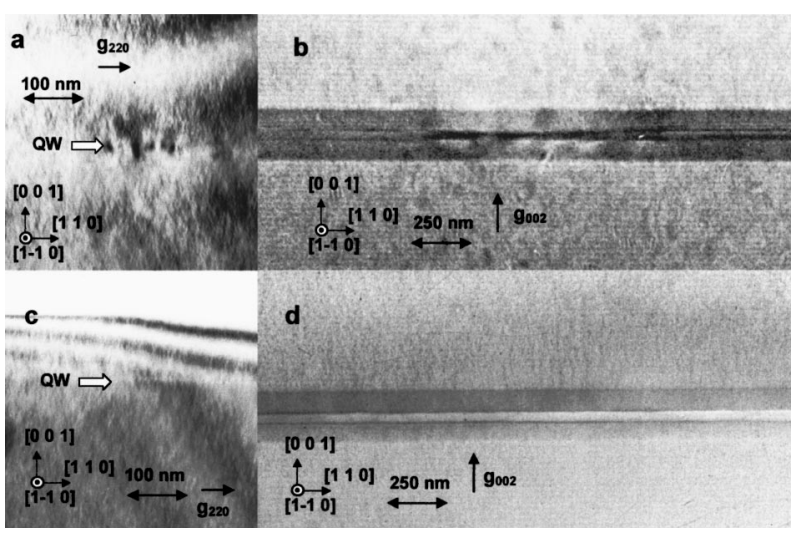

FIG. 3. Cross-sectional transmission electron micrographs for a single $40 \AA$ $\mathrm{In}_{0.85} \mathrm{Ga}_{0.15} \mathrm{As}$ QW grown by conventional MBE (a), (b) and using FMS growth (c), (d). The images were taken on the [110] projection with $g$ $=[220]$ (a), (c) and $g=[002]$ (b), (d). Images (a) and (c) are strain sensitive, whereas images (b) and (d) are composition sensitive.

wavelengths, while keeping good optoelectronic quality. This is illustrated in Fig. 2 which presents the room temperature PL spectra from a $\left[(\mathrm{InAs})_{2} /(\mathrm{GaAs})_{0.25}\right] \times 9 \mathrm{QW}$ (equivalent to a $60 \AA \mathrm{In}_{0.89} \mathrm{Ga}_{0.11}$ As QW) that exhibits a high intensity emission at $2.35 \mu \mathrm{m}$. The equivalent well grown by standard MBE was relaxed and had low intensity photoluminescence.

The structural quality of the two pseudomorphic $40 \AA$ $\mathrm{In}_{0.85} \mathrm{Ga}_{0.15} \mathrm{As} \mathrm{QWs}$ grown using conventional $\mathrm{MBE}$ and the FMS approach was examined by TEM. Figure 3 shows cross-sectional transmission electron micrographs in the [110] projection with $g=[002]$ (composition sensitivity) and $g=[220]$ (strain sensitivity). The conventionally grown QW is characterized by flat interfaces in most parts of the well, but there is a low density of perturbed areas. In these zones, both strain and composition inhomogeneities are observed [Figs. 3(a) and 3(b)]. The QW thickness is reduced, leading to groove-like defects, whereas the alloy composition appears to be indium rich in the well and gallium rich in the barrier. These perturbed areas can explain the broadening of the photoluminescence peaks. This type of groove-like defect has already been observed in $\mathrm{In}_{0.82} \mathrm{Ga}_{0.18} \mathrm{As} \mathrm{QWs}$ grown on InP. ${ }^{10}$ As suggested by Lacombe et al.,${ }^{10}$ we believe that these perturbed areas are nucleation sites for 3D islands. The growth mechanism of conventionally grown strained layers is understood as follows. As growth of compressively strained InGaAs proceeds, surface roughness appears progressively. Roughness is associated with surface ripples which lower the elastic strain energy. ${ }^{11,12}$

In contrast to conventionally grown QWs, FMS based QWs present perfect flat interfaces with no strain, composition, or thickness inhomogeneities. The FMS-based QWs appear to be of much higher structural quality. This can partly explain their better optoelectronic quality, shown in Fig. 1. We explain the higher structural quality of FMS-grown layers and their higher critical thickness by a smoother growth front and a decrease of the strain energy due to lateral composition modulation. For FMS-based QWs, we propose the following growth model. After deposition of 1.5-2 ML of InAs the growth front should show platelets separated by holes. Due to the resulting strain fields between the platelets, $\mathrm{Ga}$ atoms will be preferentially incorporated into the holes.
This will reduce the total strain energy of the system by lateral and vertical strain compensation. This mechanism will result in some composition modulation and smoothing of the growth front. As a smooth surface has a lower surface energy than a rough surface, ${ }^{13}$ this explains why the $2 \mathrm{D} / 3 \mathrm{D}$ growth mode transition is delayed in FMS growth. A smooth surface could also reduce nucleation of dislocation loops and delay plastic relaxation in the 2D growth mode, as was observed. Strain compensation occurring during composition modulation, as described above, helps to minimize the strain energy. This further explains the higher critical thickness for fractional monolayer superlattices than for standard materials. However, apart indirectly (critical thickness delayed, growth front smoothed), we do not have any specific evidence for lateral ordering. Cross-sectional and plan-view scanning tunneling microscopy could help in experimentally checking this assumption.

To our knowledge, the $2.35 \mu \mathrm{m}$ observed is the longest wavelength obtained in InGaAs QW grown on InP at such a high temperature $\left(500^{\circ} \mathrm{C}\right)$. It should be mentioned that some other methods have been reported to increase the 2D/3D critical thickness. For example, Tournié et al. ${ }^{14}$ have shown that decreasing the growth temperature to $400{ }^{\circ} \mathrm{C}$ and using virtual surfactant conditions (indium stabilization) allow 2D growth of high quality InAs QWs on InP which exhibit a room temperature PL line at $2.38 \mu \mathrm{m}$. However such an approach needs growth interruption and low growth temperatures which make the method not very applicable for device fabrication.

To conclude, we have shown that using $(\mathrm{InAs})_{n} /(\mathrm{GaAs})_{m}$ fractional monolayer superlattices improves the optical quality of strained InGaAs QWs compared to conventional procedures. In addition, the critical thickness for plastic relaxation and strain-induced in-plane inhomogeneities are reduced. The technique is directly applicable to the growth of various optoelectronic device heterostructures (such as QW lasers), because growth can be carried out at high temperatures $\left(\sim 500^{\circ} \mathrm{C}\right)$, with no substrate temperature adjustments and no growth interruption.

${ }^{1}$ S. Forouchar, A. Ksendzov, A. Larson, and H. Temkin, Electron. Lett. 28, 1431 (1992)

${ }^{2}$ J. S. Wang, H. H. Lin, and L. W. Sung, IEEE J. Quantum Electron. 34, 1959 (1998).

${ }^{3}$ A. G. Dentai, R. Kuchibotla, J. C. Campbell, C. Tsai, and C. Lei, Electron. Lett. 27, 2125 (1991)

${ }^{4}$ S. Jourba et al., Proc. SPIE 3629, 30 (1999).

${ }^{5}$ F. Glas, J. Appl. Phys. 62, 3201 (1987).

${ }^{6}$ K. Y. Cheng, K. C. Hseich, and J. N. Baillargeon, Appl. Phys. Lett. 60, $2892(1992)$

${ }^{7}$ J. Mirecki-Millunchick, R. D. Twesten, S. R. Lee, D. M. Follstaed, E. D. Jones, S. P. Ahrenkiel, Y. Zhang, H. M. Cheong, and A. Mascarenhas, MRS Bull. 38, (1997).

${ }^{8}$ J. P. Andre, A. Deswarte, E. Lugagne-Delpon, P. Voisin, and P. Ruterana, J. Electron. Mater. 23, 141 (1994).

${ }^{9}$ D. Saito, H. Yonesu, T. Kawai, M. Yokozeki, and K. Pak, Jpn. J. Appl. Phys., Part 2 33, L1205 (1994).

${ }^{10}$ D. Lacombe, A. Ponchet, S. Frechengues, V. Drouot, B. Lambert, and A. LeCorre, J. Cryst. Growth (to be published).

${ }^{11}$ J. Tersoff and F. K. LeGoues, Phys. Rev. Lett. 72, 3570 (1994).

${ }^{12}$ B. G. Orr, D. Kessler, C. W. Snyder, and L. Sander, Europhys. Lett. 19, 33 (1992).

${ }^{13}$ M. Gendry, G. Grenet, Y. Robach, P. Krapf, and G. Hollinger, Phys. Rev. B 56, 9271 (1997).

${ }^{14}$ E. Tournié, O. Brandt, C. Giannini, and K. H. Ploog, J. Cryst. Growth 127, 765 (1993).

AIP license or copyright, see http://ojps.aip.org/aplo/aplcr.jsp 